\title{
Economics Imperialism in Law and Economics
}

\section{Malecka, Magdalena}

Springer

2019

Malecka, M 2019 , Economics Imperialism in Law and Economics . in A Marciano \& G B

Ramello (eds) , Encyclopedia of Law and Economics . Springer, New York . https://doi.org/10.1007/978-1-4614-788

http://hdl.handle.net/10138/311363

https://doi.org/10.1007/978-1-4614-7883-6_741-1

draft

Downloaded from Helda, University of Helsinki institutional repository.

This is an electronic reprint of the original article.

This reprint may differ from the original in pagination and typographic detail.

Please cite the original version. 
Economic Imperialism in Law and Economics

\section{Magdalena Małecka}

TINT - Centre for Philosophy of Social Science,

\section{Definition}

Economics imperialism is a type of an interdisciplinary relation between the scientific discipline of economics and other disciplines of the social sciences. The disciplines that are often claimed to be "imperialized" by economics are sociology (see Granovetter and Swedberg 2001; Swedberg 1990), political science (see Hodgson 1994; Sigelman and Goldfarb 2012; Kuorikoski and Lehtinen 2010), anthropology (see Marchionatti and Cedrini 2016), geography (see Mäki and Marchionni 2010), and law (see Medema 2018; Davies 2010; Fink 2003). Hence, the law and economics movement is seen by some as one of the manifestations of the imperialism of economics in the social sciences (in this case - in legal scholarship). Below, I review the general debate on economics imperialism, and then I discuss the attempts to analyze law and economics as a case of economics imperialism.

\section{Introduction}

Recently, in the philosophy of science literature 28 there is a discussion on scientific imperialism, of 29 which economics imperialism is just an instance. 30 This debate has revolved around the question of 31 the permissibility of the application of scientific 32 theories and methods outside the discipline in 33 which they were initially introduced. Philoso- 34 phers of science have attempted to clarify what it 35 means for a theory or a discipline to be applied 36 outside its own field or domain, and whether such 37 an application can be understood as imperialistic 38 (Dupré 1994, 2001; Mäki 2013; Clarke and Walsh 39 2009; Kidd 2013; Clarke and Walsh 2013; contri- 40 butions to the volume edited by Mäki et al. 2017). 41 It is debated whether scientific imperialism is a 42 neutral or normatively loaded term, how to estab- 43 lish criteria for assessment of imperialistic prac- 44 tices in science, how to categorize different 45 instances of scientific imperialism, as well as 46 whether the political metaphor of imperialism is 47 useful at all in order to account for relationships 48 between scientific disciplines. Mäki et al. (2017) 49 argue that scientific imperialism challenges two 50 central tenets of current scientific practice, as it 51 calls into question two widely spread ideas: 52 (1) that the broader the scope of a scientific theory, 53 the better; (2) that interdisciplinary exchanges 54 bring indisputable benefits (p. 1).

The term "economics imperialism" has been 56 used in the pejorative sense by the critics of the 57 idea of applying economics outside its domain 58 
(Fine and Milonakis 2009; Davis 2015; Hodgson 1994; Nik-Khah and Van Horn 2012) and in the approbatory sense by some economists (most notably by Becker 1971; Hirshleifer 1985; Stigler 1984; Lazear 2000; Radnitzky and Bernholz 1987; Tullock 1972) who have advocated the idea of expanding economic theories and methods to the topics studied by the less advanced, in their opinion, social sciences. "Economics imperialists" have argued that such an expansion is justified by economics' "growing abstractness" and "generality" that economics achieves thanks to "the machine of maximizing behavior" (Stigler 1984); by the universal applicability of economics' analytical categories (Hirshleifer 1985); and by economics' intellectual rigor (Lazear 2000; Posner 1989). Moreover, Mäki (2009) emphasizes that the expansion of economics has been often justified in terms of the ideal of unification economics is supposed to provide, in the opinion of "imperialists," a unifying theory for the social sciences. Fine and Milonakis (2009) claim that the theoretical development in economics that made the expansion of economics possible was the marginalist revolution and its basic concepts of equilibrium (see: $>$ "Equilibrium Theory"), rationality (see: " "Rationality"), scarcity - "universal in content and application" (p. 8).

\section{Criticism of Economics Imperialism}

However, critics of economics imperialism, apart from questioning the alleged advancement of economics as a social science, often point out the importance of non-epistemic arguments and nonacademic standing of economics for the successes of its imperialistic scientific practices. For instance, Nik-Khah and Van Horn (2012) claim that economics imperialists of the Chicago School wanted in the first place to influence policy approach by proposing their view on what constitutes the economic analysis of state policy. "Stigler's program to study 'governmental control' constituted a new and distinct approach, rather than mere application of a core Chicago approach to a new domain" (p. 217) (see: - "Stigler"). Amadae (2018) stresses the importance of politically motivated expansion of 104 the rational choice theory - its attractiveness for 105 nuclear deterrence made it prestigious in non- 106 academic contexts and in this way has strengthened 107 its standing within academia as well. In this context 108 the affinities of the Chicago School analysis with 109 neoliberalism are often emphasized. Nik-Khah and 110 Van Horn (2012) claim that economics imperialism 111 cannot be really understood if one does not take 112 into account the Chicago School economists' 113 involvement into the revival of the liberal project, 114 known as neoliberalism - redefinition of the social 115 and the political sphere through the concepts of 116 neoclassical economics - and its impact on the 117 real-world policy design. Therefore, partly in 118 response to this "performative" aims of the Chi- 119 cago School (Davis 2015), or "pedagogical" effects 120 of the rational choice theory (Amadae 2018), some 121 critics of economics imperialism have argued that 122 the conceptualization of social relationships 123 through the categories of neoclassical economics, 124 or of rational choice, is inherently inadequate (Fine 125 and Milonakis 2009) and can lead to ethically 126 objectionable large-scale sociocultural conse- 127 quences (Marino 2018) by influencing agents' 128 self-understanding (Clarke and Walsh 2009). 129

\section{Is All Economics Imperialistic?}

It should be noticed, however, that upon inspec- 131 tion we find out that economics imperialism, as 132 each instance of scientific imperialism, is in fact a 133 relationship between smaller epistemic units than 134 scientific disciplines (Davis 2015; Małecka and 135 Lepenies 2018; Chassonnery-Zaïgouche 2018). 136 The analysis of cases of economics imperialism 137 makes it clear that it is never the case that the 138 whole discipline of economics is "imperializing," 139 e.g., the whole sociology. Thus, as Davis (2012) 140 argues, "economics is not all economics" (p. 210). 141 It is usually a particular research program that 142 develops within the discipline of economics and 143 which is being transferred outside, as well as 144 within, economics' institutional borders. 145

In contemporary discussions, it is often 146 claimed that only neoclassical economics, and 147 more specifically the Chicago School and its 148 
price theory, are extended to other domains and scientific fields (Davis 2015; Nik-Khah and Van Horn 2012). However, Amadae (2018) argues that it is in fact not the neoclassical economics with its formalization of diminishing marginal utility, what constitutes economics imperialism, but rather the game theory with its view on agency as strategic competition between actors who satisfy their preferences. Guilhot and Marciano (2018) complicate the picture by showing that what is now called the economics imperialism in political science was the application of the rational choice theory to the questions of the political decision-making: it was possible rather due to the rising importance of the decision theory across the social and behavioral sciences after the Second World War. Furthermore, few researchers emphasize that some of the economic approaches, or research programs that we consider imperialistic today, were in fact quite marginal within economics, back in the days. Becker's (see - "Becker") application of rational choice and price theory to the analysis of social phenomena is one of the examples (Chassonnery-Zaïgouche 2018; Vromen 2009). Chassonnery-Zaïgouche (2018) analyzes economic studies of discrimination and claims that Becker influenced, imperialized, with his work mainly the discipline of economics and has had, in fact, marginal impact on other social sciences studying discrimination.

Despite the seemingly intuitive appeal of the term "economics imperialism," it is not clear what does it mean that one research program is imperializing another, or other. Economics imperialism has been defined, for instance, as "colonisation of the subject matter of other social sciences by economics" (Fine and Milonakis 2009), as "a form of economics expansionism where the new types of explanandum phenomena are located in territories that are occupied by disciplines other than economics" (Mäki 2009), or as "the attempt to extend the core ideas of neoclassical economics to cover social science as a whole" (Hodgson 1994). Most of the definitions account for the metaphorical use of the notion of imperialism as we know it in political context. There is a discussion, however, to what extent the metaphor of imperialism should be taken seriously when 197 talking about scientific practices. The notion of 198 imperialism is normatively loaded and most 199 scholars believe that one cannot ignore this nor- 200 mative dimension in the case of economics impe- 201 rialism (Mäki 2013, who defines scientific, and 202 economics, imperialism neutrally, is an exception 203 here). Małecka and Lepenies (2018) provide the 204 definition of scientific imperialism, that applies to 205 economics imperialism, in which they account for 206 the widely shared believe that there is something 207 normatively problematic about economics impe- 208 rialism. They stress the importance of epistemic 209 and non-epistemic factors for being able to define 210 and identify economics imperialism. Scientific 211 imperialism is an activity that is related both to a 212 certain view on the progressive character of a 213 novel application of an existing research approach 214 (the epistemic aspect) and to a power to favor this 215 approach at the expense of other approaches in 216 terms of academic and nonacademic prestige, 217 or/and resources (the institutional aspect).

\section{Law and Economics as an Instance of Economics Imperialism}

Law and economics is often seen as a result of the 221 expansion of the Chicago School approach to law 222 (Mercuro and Medema 2006; Medema 2015, 223 2018). Sometimes it is understood, more broadly, 224 as an application of orthodox, or neoclassical eco- 225 nomics (Jackson 1984; Davies 2010), or of game 226 theory (Pearson 1997) to law (see " "Game The- 227 ory Applications to Law"). Mercuro and Medema 228 (2006) even argue that law and economics "has 229 been the most successful of economists' imperi- 230 alistic forays into other disciplines" (p. 100). 231

The application of the price theory to the anal- 232 ysis of law is grounded on the premise that indi- 233 viduals are rational maximizers of their utility, that 234 they respond to price incentives also in non- 235 economic settings and that law can be treated as 236 an incentive. Medema (2015) stresses the impor- 237 tance of Gary Becker's (see - "Becker") works 238 that advanced the analysis of all social phenomena 239 with the tools of price theory (and econometrics) 240 for the development of economic analysis of law. 241 
Medema (2015) differentiates this "new" law and economics, inspired by the work of Becker, as well as of Richard Posner (see "Posner"), from the "old" one, initiated by Aaron Director (see $\triangleright$ "Director"), whose aim was to simply analyze the impact of legal rules on economic performance. According to Medema only the "new" law and economics has features of scientific (economics) imperialism (compare also Epstein 1997 on periodization of law and economics and Harnay and Marciano (2009) on the difference between law and economics and economic analysis on law).

Posner (1989) justifies the application of neoclassical economics to law by the rigor that this type of economic analysis allegedly offers, as well as by the possibility of funding the truly "scientific" analysis of law in this way. Cooter (1981) points out that the reason for the economics imperialism in law is the "discovery" by economists a niche in legal scholarship - a lack of quantitative reasoning. Cooter (1995) also emphasizes the importance of an attempt for unification for applying economics to law.

The historical case study made by Medema (2018) on the ad hoc Joint Committee of the American Economic Association and the Association of American Law Schools established in 1966 to explore the prospects for interactions between lawyers and economists challenges the commonly spread narrative about neoclassical economists conquering a new field. The study demonstrates that lawyers played a crucial role at the early stage of bringing economics to their studies and in replacing "the traditional methods of legal analysis" (Medema 2018, p. 110). However, later on the application of neoclassical economics to law had been opposed by some lawyers as being too abstract an analysis, untested, irrelevant to the courtroom (Cooter 1981). Law and economics as a scientific project of explaining legal phenomena has been also scrutinized and criticized. For instance, Jackson (1984) criticized law and economics' scientism and its technocratic attitude that made it so dominant in the legal scholarship. For other critics law and economics is mainly a manifestation of "the neo-liberal project of applying neo-classical economics to state sovereignty" (Davies 2010, p. 64) that has been 290 advanced by non-epistemic arguments and nor- 291 mative views on policy as complying with the 292 goals of economic efficiency (Davies 2010; Fink 293 2003).

\section{Cross-References}

Becker

Equilibrium Theory

Posner, Richard

Rationality

\section{References}

Amadae SM (2018) Economics imperialism reconsidered. 301 In: Scientific imperialism: exploring the boundaries of 302 interdisciplinarity. p 4

Becker GS (1971) Economic theory. Alfred A. Knopt, 304 New York

Chassonnery-Zaïgouche C (2018) Crossing boundaries, 306 displacing previous knowledge and claiming superior- 307 ity. In: Scientific imperialism: exploring the boundaries 308 of interdisciplinarity. p 31

Clarke S, Walsh A (2009) Scientific imperialism and the 310 proper relations between the sciences. Int Stud Philos 311 Sci 23(2):195-207

Clarke S, Walsh A (2013) Imperialism, progress, develop- 313 mental teleology, and interdisciplinary unification. 314 Inter Stud Philos Sci 27(3):341-351 315

Cooter RD (1981) Law and the imperialism of economics: 316 an introduction to the economic analysis of law and a 317 review of the major books. UCLA Law Rev 29:1260 318

Cooter R (1995) Law and unified social theory. J Law Soc 319 22(1):50-67

Davies W (2010) Economics and the 'nonsense' of law: the 321 case of the Chicago antitrust revolution. Econ Soc 322 39(1):64-83

Davis JB (2012) Mäki on economics imperialism. In: Eco- 324 nomics for real: Uskali Mäki and the place of truth in 325 economics. pp 203-219

Davis JB (2015) Economics imperialism versus 327 multidisciplinarity 328

Dupré J (1994) Against scientific imperialism. In PSA: 329 proceedings of the Biennial meeting of the philosophy 330 of science association, Philosophy of Science Associa- 331 tion, vol 1994, no 2, pp 374-381 332

Dupré J (2001) Human nature and the limits of science. 333 Clarendon Press, Oxford

B, Milonakis D (2009) From economics imperialism 335 to freakonomics: the shifting boundaries between eco- 336 nomics and other social sciences. Routledge, 337 London/New York 
Fink EM (2003) Post-realism, or the jurisprudential logic of late capitalism: a socio-legal analysis of the rise and diffusion of law and economics. Hastings LJ, 55, 931

Granovetter M, Swedberg R (2001) The sociology of economic life, 2nd edn. Westview Press, Boulder

Guilhot N, Marciano A (2018) Rational choice as neodecisionism. In: Scientific imperialism: exploring the boundaries of interdisciplinarity

Harnay S, Marciano A (2009) Posner, economics and the law: from "law and economics" to an economic analysis of law. J Hist Econ Thought 31(2):215-232

Hirshleifer J (1985) The expanding domain of economics. Am Econ Rev 75(6):53-68

Hodgson GM (1994) Some remarks on 'economic imperialism'and international political economy. Rev Int Polit Econ 1(1):21-28

Jackson N (1984) The economic explanation of legal phenomena. Int Rev Law Econ 4(2):163-183

Kidd JI (2013) Historical contingency and the impact of scientific imperialism. Int Stud Philos Sci 27(3):315-324

Kuorikoski J, Lehtinen A (2010) Economics imperialism and solution concepts in political science. Philos Soc Sci 40(3):347-374

Lazear EP (2000) Economic imperialism. Q J Econ 115(1):99-146

Mäki U (2009) Economics imperialism: concept and constraints. Philos Soc Sci 39(3):351-380

Mäki U (2013) Scientific imperialism: difficulties in definition, identification, and assessment. Int Stud Philos Sci 27(3):325-339

Mäki U, Marchionni C (2010) Is geographical economics imperializing economic geography? J Econ Geogr 11(4):645-665

Mäki U, Walsh A, Pinto MF (eds) (2017) Scientific imperialism: exploring the boundaries of interdisciplinarity. Routledge, Oxon

Małecka M, Lepenies R (2018) Is the behavioral approach a form of scientific imperialism? An analysis of law and policy. In: Mäki U, Walsh A, Pinto MF (eds) Scientific imperialism: exploring the boundaries of interdisciplinarity. Routledge, Abingdon
Marchionatti R, Cedrini M (2016) Economics as social 381 science: economics imperialism and the challenge of 382 interdisciplinarity. Taylor \& Francis, Basingstoke $\quad 383$

Marino P (2018) Ethical implications of scientific imperi- 384 alism. Two examples from economics. In: Scientific 385 imperialism: exploring the boundaries of 386 interdisciplinarity 387

Medema SG (2015) From dismal to dominance? Law and 388 economics: philosophical issues and fundamental ques- 389 tions 22: 69

Medema SG (2018) Scientific imperialism or merely 391 boundary crossing? In: Scientific imperialism: explor- 392 ing the boundaries of interdisciplinarity 393

Mercuro N, Medema SG (2006) Economics and the law: 394 from posner to postmodernism and beyond, 2nd edn 395

Nik-Khah E, Van Horn R (2012) Inland empire: economics 396 imperialism as an imperative of Chicago neoliberalism. 397 J Econ Methodol 19(3):259-282 398

Pearson H (1997) Origins of law and economics: the econ- 399 omists' new science of law, 1830-1930. Cambridge 400 University Press, New York 401

Posner R (1989) Foreword. In: Faure M, van den Bergh 402 $\mathrm{R}$ (eds) Essays in law and economics: corporations, 403 accident prevention and compensation for losses. 404 Maklu, Antwerpen 405

Radnitzky G, Bernholz P (eds) (1987) Economic imperial- 406 ism: the economic approach applied outside the field of 407 economics. Paragon House Publishers, New York 408

Sigelman L, Goldfarb R (2012) The influence of econom- 409 ics on political science: by what pathway? J Econ 410 Methodol 19(1):1-19 411

Stigler GJ (1984) Economics: the imperial science? Scand 412 J Econ 86(3):301-313 413

Swedberg R (1990) Economics and sociology: redefining 414 their boundaries: conversations with economists and 415 sociologists. Princeton University Press, Princeton 416

Tullock G (1972) Economic imperialism. In: Theory of 417 public choice. pp 317-29 418

Vromen JJ (2009) The booming economics-made-fun 419 genre: more than having fun, but less than economics 420 imperialism. Erasmus J Philos Econ 2(1):70-99 421 
Author Queries

Encyclopedia of Law and Economics

Chapter No.: 741-1

\begin{tabular}{|c|c|c|}
\hline Query Refs. & Details Required & Author's response \\
\hline AU1 & $\begin{array}{l}\text { Please be aware that your name and affiliation and if } \\
\text { applicable those of you co-author(s) will be published as } \\
\text { presented in this proof. If you want to make any } \\
\text { changes, please correct the details now. Note that } \\
\text { corrections after publication will no longer be possible. }\end{array}$ & yes, it's ok \\
\hline AU2 & Please provide synonyms. & synonyms to which word? \\
\hline AU3 & $\begin{array}{l}\text { Mäki et al. } 2018 \text { has been changed to Mäki et al. } 2017 \\
\text { here and in other occurrences as per the reference list. } \\
\text { Please check if okay. }\end{array}$ & It should be 2018 \\
\hline AU4 & $\begin{array}{l}\text { Please provide editors and publisher details for Amadae } \\
\text { (2018), Chassonnery-Zaïgouche (2018), Davis (2012), } \\
\text { Guilhot and Marciano (2018), Marino (2018), Medema } \\
\text { (2018), Tullock (1972), Zaïgouche (2018). }\end{array}$ & $\begin{array}{l}\text { Routledge: Amadae, Chassonery-Zaigou } \\
\text { and Marciano, Marino, Medema, Davis } \\
\text { The University of Michigan Press: Tullo }\end{array}$ \\
\hline AU5 & $\begin{array}{l}\text { Please provide publisher details for Davis (2012), } \\
\text { Mercuro and Medema (2006). }\end{array}$ & $\begin{array}{l}\text { Davis - Routledge } \\
\text { Mercuro and Medema -Princeton Uni }\end{array}$ \\
\hline AU6 & Please check if the inserted publisher location is okay. & yes \\
\hline
\end{tabular}

\section{Note:}

If you are using material from other works please make sure that you have obtained the necessary permission from the copyright holders and that references to the original publications are included. 